\title{
Application of in-situ produced terrestrial cosmogenic nuclides to archaeology: A schematic review
}

\author{
NAKi AkÇar, Susan Ivy-Ochs \& Christian Schlüchter ${ }^{*)}$
}

\begin{abstract}
The wide applicability of in-situ produced Terrestrial Cosmogenic Nuclides (TCNs) to geological problems and experiences in development and testing gained over the past decade is encouraging for its application to archaeological questions, where there is a distinct need for an additional independent dating tool beyond the limits of radiocarbon $(\sim 40 \mathrm{ka})$. Just as TCNs are applicable to a broader time period with considerable precision in archaeology, so also are they applicable to all lithologies. Application of TCNs to archaeological problems is relatively simple: either surface exposure dating (using cosmogenic nuclide production) or burial dating (using decay of radioactive cosmogenic nuclides) can be applied. For a successful application, close collaboration between archaeologists and TCN experts is required. The total exposure from 100 a to $5 \mathrm{Ma}$ of a given surface of archaeological origin can be determined by surface exposure dating. The range of burial dating is from $\sim 0.1$ to $5 \mathrm{Ma}$. TCNs have been successfully applied to many archaeological problems during the last decade and both surface exposure dating and burial dating show high potential in the solving of archaeological problems.
\end{abstract}

[Anwendung in-situ produzierter, terrestrischer kosmogener Nuklide in der Archäologie: Ein schematischer Überblick]

Kurzfassung: Die breite Anwendbarkeit von in-situ produzierten Terrestrischen Kosmogenen Nukliden (TCN) in geologischen Fragestellungen und die damit verbundenen Erfahrungen in der Entwicklung und Eignungsprüfung die im letzten Jahrzehnt erlangt wurden, ermutigen diese Methode auch für archäologische Fragestellungen anzuwenden. In diesem Zusammenhang gibt es ein konkretes Bedürfnis für eine zusätzliche unabhängige Methode der Altersbestimmung jenseits der Grenze von Radiokohlenstoff ( $40 \mathrm{ka})$. TCN sind nicht nur in einem Grenzbereich mit einer gewissen Präzision anwendbar, sie sind auch geeignet für die unterschiedlichsten Lithologien. Die Anwendung von TCN in archäologischen Fragestellungen ist relativ einfach: entweder wird der Ansatz der Oberflächendatierung gewählt (Nutzung der Produktion von kosmogenen Nukliden) oder man verwendet den Ansatz der Begrabungsalter (Nutzung des Zerfalls von radioaktiven kosmogenen Nukliden). Für eine erfolgreiche Anwendung der Methode ist jedoch eine enge Zusammenarbeit zwischen Archäologen und TCN Spezialisten notwendig. Eine Expositionszeit zwischen 100 a bis zu 5 Ma einer archäologisch geschaffenen Fläche kann durch Oberflächendatierung bestimmt werden. Der Altersbereich der Begrabungsaltermethode liegt zwischen $\sim 0.1$ to $5 \mathrm{Ma}$. TCN wurden während des letzten Jahrzehnts erfolgreich zur Datierung vieler archäologischer Fragestellungen angewendet und sowohl die Oberflächendatierung als auch Begrabungsaltermethode zeigen ein hohes Potenzial um archäologische Fragestellungen lösen zu können.

Keywords: Terrestrial Cosmogenic Nuclides, Archaeology, Numerical Dating

\footnotetext{
*Addresses of authors: N. Akçar, Institut für Geologie, Universität Bern, Baltzerstrasse 1+3, 3012 Bern, Switzerland. E-Mail: akcar@geo.unibe.ch; S. Ivy-Ochs, Institut für Teilchenpysik, ETH Zürich, HPK/H27, Schafmattstrasse 20, 8093 Zürich, Schweiz and Geographisches Institut, Universität Zürich (Irchel), Winterthurerstrasse 190, 8057 Zürich, Switzerland; Ch. Schlüchter, Institut für Geologie, Universität Bern, Baltzerstrasse 1+3, 3012 Bern, Switzerland.
} 


\section{Introduction}

Shrewder sampling, improved chemical sample preparation and analysis as well as a better understanding of the physical processes responsible for in-situ produced Terrestrial Cosmogenic Nuclides (TCNs) have significantly enhanced the reliability of the method since its conception (cf., Gosse \& PhiLlips 2001). The best known application of TCNs is the dating of the Quaternary ice volume fluctuations from the records archived by mountain glaciers (e.g., Ivy-Ochs et al. 2006) and continental ice sheets (e.g., Briner et al. 2006). Moreover, TCN methods have been employed in dating volcanic (e.g., LiCCIARDi et al. 1999) and palaeoseismic events (e.g., BenedetTi et al. 2003) as well as to quantify surface and/or rock uplift (Ritz et al. 2006) and incision rates (e.g., Schaller et al. 2005). Due to the sensitivity of the cosmogenic nuclide concentration to surface erosion and depth below the surface, the method has led to significant breakthroughs in establishing the rates and styles of local and large-scale erosion (SCHALler et al. 2001), soil development (HeIMSATH et al. 1997) and landscape evolution (e.g., BiERman et al. 2002). The method can also be applied to the study of surface processes over a broad range of climate settings, employing different lithologies and mineralogies (Ivy-OcHS \& KOBER 2008). In addition, several geologic anomalies have been dated by cosmogenic nuclides such as Libyan desert glass (KLEIN et al. 1986) and the Canyon Diablo meteorite impact (Nishizumi et al. 1991; Phillips et al. 1991). Depending on the surface preservation and exposure history, this dating technique has an effective range from the Pliocene to the late Holocene (Ivy-Ochs \& KOBER 2008). Its rapid and wide acceptance in using ${ }^{3} \mathrm{He},{ }^{10} \mathrm{Be},{ }^{14} \mathrm{C}$, ${ }^{21} \mathrm{Ne},{ }^{26} \mathrm{Al}$, and ${ }^{36} \mathrm{Cl}$ is not only due to its wide applicability to problems in surface geology but also to the reproducibility of many of its early results (Gosse \& PHILLIPs 2001 and references therein).

Cosmogenic nuclides can be used to exposure date fossils, lithic artefacts or monuments directly, to exposure date rock surfaces, or to date sediments associated with fossils or stone tools, or to determine nuclide concentrations to assess tool procurement strategies. Therefore, cosmogenic nuclide methods have a largely unrealized potential in archaeology (STUART 2001). Although several dating techniques such as radiocarbon (e.g., GonZALEZ et al. 2003), Useries (e.g., SHEN et al. 2001), electron spin resonance (e.g., Molodkov 2001), ${ }^{40} \mathrm{Ar} /{ }^{39} \mathrm{Ar}$ (e.g., Clark et al. 2003) and luminescence (e.g., VALLADAS et al. 2003), either directly or indirectly, can be applied to archeological problems, there is a substantial need for an additional dating tool in archaeology beyond the limits of radiocarbon and independent of the dating methods mentioned above (Fig. 1). Among several dating techniques, the TCN technique seems to be very promising due to its longer application period and efficacy without the need for any organic material (Fig. 1).

The primary focus of this review paper is on the evaluation of the application of TCNs to archaeological questions considering basically surface exposure dating and burial dating. Following the basic information on these two techniques, we discuss in detail how these techniques can be applied with assumptions, requirements, potential problems, disadvantages and advantages of each technique. This discussion is complemented with respective reviews of previous studies of TCN applications to archaeology.

\section{How to apply TCNs to archaeology?}

High-energy cosmic rays originating predominantly from super nova explosions within our galaxy are continuously bombarding the Earth. Interactions between these high-energy cosmic rays and the Earth's atmosphere create secondary and tertiary cosmic rays, including neutrons and muons. These high-energy particles can penetrate meters into rock and sediment when they reach the Earth's surface. Located in the upper surface of a rock, in-situ produced terrestrial cosmogenic nuclides are the product of the interaction of cosmic radiation, primarily neutrons, with a variety of target atoms within 


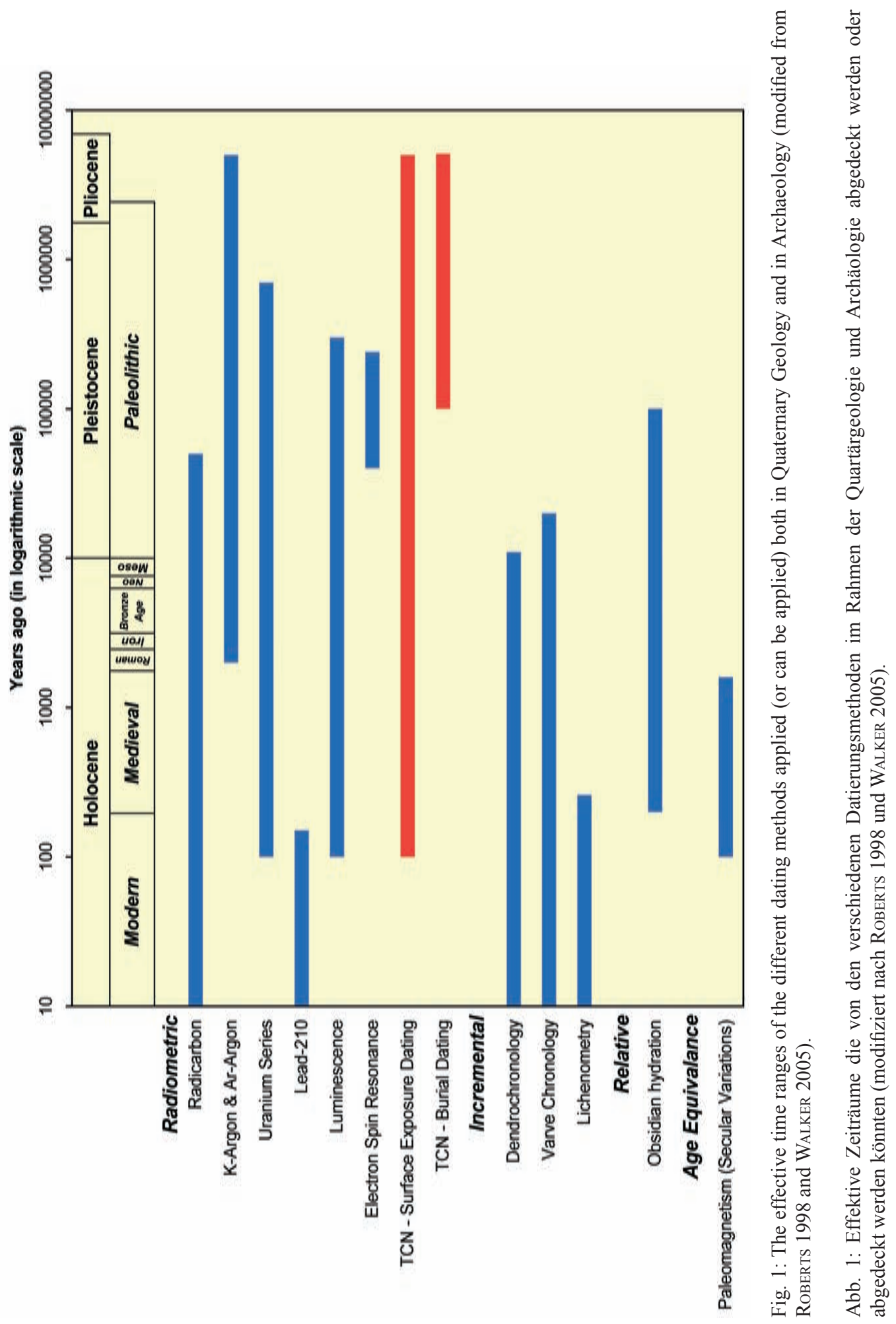


minerals (e.g., quartz, calcite, K-feldspar and olivine). This interaction results in nuclear reactions such as spallation (the splitting of nuclei), muon-induced reactions and neutron capture reactions (LAL \& Peters 1967; ReEdy 1987; LAL 1988). In consequence of these reactions, unstable cosmogenic nuclides such as ${ }^{10} \mathrm{Be},{ }^{14} \mathrm{C},{ }^{26} \mathrm{Al}$, and ${ }^{36} \mathrm{Cl}$ and stable cosmogenic nuclides such as ${ }^{3} \mathrm{He}$ and ${ }^{21} \mathrm{Ne}$ are produced in respective mineral lattices (Table 1) (cf., IvYOCHS \& Kober 2008).

Theoretically, application of TCNs to archaeological problems is relatively simple. Either the production (both stable and unstable) or decay (in the case of unstable) cosmogenic isotopes can be applied. Surface exposure dating is the most common field of the cosmogenic nuclide technique (cf., Ivy-Ochs \& Kober 2008), while burial dating, based on TCN decay, is now also increasingly used (cf., DeHNERT \& SCHLÜCHTER 2008). Essentially, surface exposure dating can be applied over the timescales of around 100 a to $5 \mathrm{Ma}$ and burial dating over around 0.1 to $5 \mathrm{Ma}$. The difference between the lower limits originates directly from the time required for a sufficient decay of unstable cosmogenic nuclides in order to detect different isotopic concentrations due to various half-lives. Both surface exposure and burial dating tools require that the archaeological sample to be dated is destroyed during the sample preparation, and this can make the application of TCNs to archaeology at first seem strange. However, a destruction of this type can be minimized with careful planning of the sampling strategy and analysis of the scientific problem. In spite of this, the number of samples required for such analysis should be in the order of five.

\subsection{Surface exposure dating}

The application of surface exposure dating to archaeology at first sight appears to be restricted to large archaeological structures such as buildings, monuments and standing stones (StUART 2001). However the situation is simpler: if the concentration of the required TCN can be measured with accelerator mass spectrometry, the total exposure duration (from 100 a to $5 \mathrm{Ma}$ ) of a given surface can be deter-

Table 1: Characteristics of unstable cosmogenic nuclides ${ }^{10} \mathrm{Be},{ }^{26} \mathrm{Al}$, and ${ }^{36} \mathrm{Cl}$ and stable cosmogenic nuclides ${ }^{3} \mathrm{He}$ and ${ }^{21} \mathrm{Ne}$ (modified after Ivy-Ochs \& Kober 2007).

Tabelle 1: Charakteristiken der instabilen kosmogenen Nuklide ${ }^{10} \mathrm{Be},{ }^{26} \mathrm{Al}$, und ${ }^{36} \mathrm{Cl}$ und der stabilen kosmogenen Nuklide ${ }^{3} \mathrm{He}$ und ${ }^{21} \mathrm{Ne}$ (verändert nach Ivy-Ochs \& KoBer 2007).

\begin{tabular}{|c|c|c|c|c|}
\hline TCN & $\begin{array}{l}\text { Production Rate* } \\
\left(\text { atoms } \mathrm{g}^{-1} \mathrm{a}^{-1}\right)\end{array}$ & $\begin{array}{l}\text { Half-life } \\
(\mathrm{Ma})\end{array}$ & $\begin{array}{l}\text { Target } \\
\text { Elements }\end{array}$ & Target Minerals \\
\hline${ }^{3} \mathrm{He}$ & $\begin{array}{l}119 \\
\text { (LiCCARDI et al. 1999) }\end{array}$ & Stable & Many & $\begin{array}{l}\text { Olivine } \\
\text { Pyroxene }\end{array}$ \\
\hline${ }^{10} \mathrm{Be}$ & $\begin{array}{l}5.1 \\
(\text { STONE 2000) }\end{array}$ & $\begin{array}{l}1.51 \\
\text { (HoFMANN et al. 1987) }\end{array}$ & $\begin{array}{l}\mathrm{O} \\
\mathrm{Si}\end{array}$ & Quartz \\
\hline${ }^{21} \mathrm{Ne}$ & $\begin{array}{l}20.33 \\
\text { (NIEDERMANN 2000) }\end{array}$ & Stable & $\begin{array}{l}\mathrm{Si} \\
\mathrm{Mg}\end{array}$ & $\begin{array}{l}\text { Quartz, Olivine } \\
\text { Pyroxene }\end{array}$ \\
\hline${ }^{26} \mathrm{Al}$ & $\begin{array}{l}30.1 \\
(\text { STONE 2000) }\end{array}$ & $\begin{array}{l}0.716 \\
\text { (SAMWORTH et al. 1972) }\end{array}$ & $\mathrm{Si}$ & Quartz \\
\hline${ }^{36} \mathrm{Cl}$ & $\begin{array}{l}\text { Lithology dependent } \\
\text { ca. } 10 \text { in granite } \\
20 \text { in limestone }\end{array}$ & 0.301 & $\begin{array}{l}\mathrm{K} \\
\mathrm{Ca} \\
{ }^{35} \mathrm{Cl}\end{array}$ & Whole Rock \\
\hline
\end{tabular}

*Nuclide production rates at sea level and high latitude (GoSSE \& PHILLIPS 2001). 


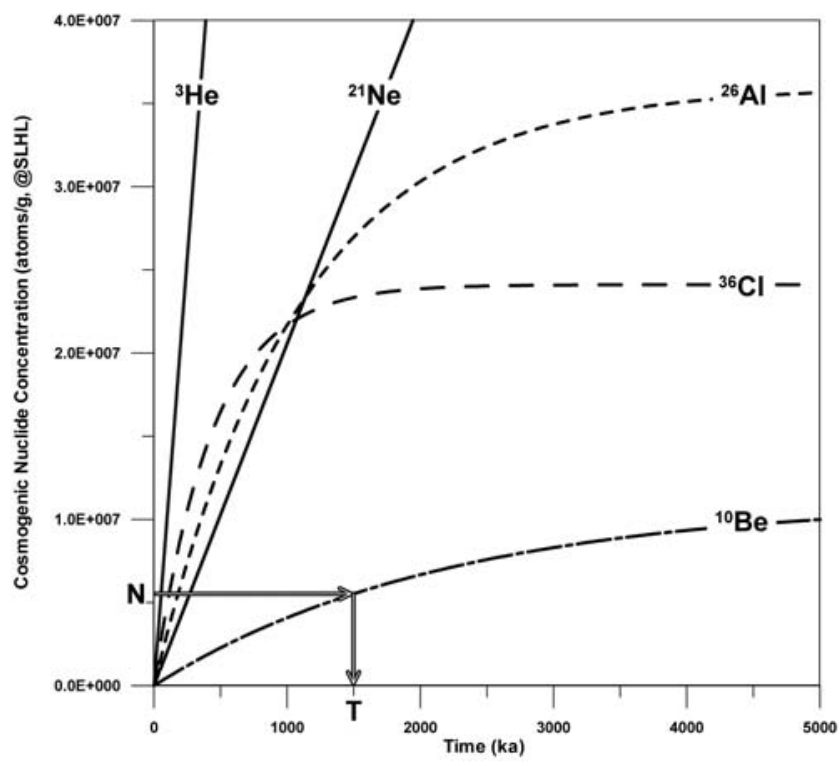

Fig. 2: Accumulation of ${ }^{3} \mathrm{He},{ }^{10} \mathrm{Be},{ }^{21} \mathrm{Ne},{ }^{26} \mathrm{Al}$ and ${ }^{36} \mathrm{Cl}$ in a rock surface as a function of exposure time at sea level high latitude (@SLHL). N is the concentration of the cosmogenic nuclide and $\mathrm{T}$ is the equivalent time of exposure. TCN concentrations were calculated with CosmoCalc 1.0 (VERMEESCH 2007), using STONE (2000) scaling factors and default values.

Abb. 2: Akkumulation von ${ }^{3} \mathrm{He},{ }^{10} \mathrm{Be},{ }^{21} \mathrm{Ne},{ }^{26} \mathrm{Al}$ und ${ }^{36} \mathrm{Cl}$ in Gesteinsoberflächen als Funktion der Expositionszeit im Meeresspiegelniveau (@SLHL). N ist die Konzentration des kosmogenen Nuklids und $\mathrm{T}$ ist die Equivalenzzeit an Exposition. TCN Konzentrationen wurden mit Hilfe von CosmoCalc 1.0 (VermeEsch 2007) kalkuliert, unter Anwendung der Skalierungsfaktoren und Vorgaben nach Stone (2000).

mined (Fig. 2) using the local production rate of the respective isotope (Table 1) (Ivy-Ochs \& Kober 2008). For this determination, three conditions must be fulfilled. The first is that the cosmogenic isotope concentration at the beginning of exposure is zero or known (i.e. inheritance). The second is that the system must have been closed with respect to either gain or loss of the respective isotope. The third assumption is that the correct production rates are known and were constant during the exposure time.

Cerling \& Craig (1994) were the first scientists who discussed the potential application of cosmogenic nuclides to archaeology in their review publication "Geomorphology and Cosmogenic Nuclides" and suggested that the pyramids, Sphinx, Stonehenge or even the statues on Easter Island could be directly exposure dated. For instance, initial results from the analysis of ${ }^{36} \mathrm{Cl}$ in the bluestones from Stonehenge are controversial (WILLIAMS-THORPE et al. 1995). Furthermore they describe the debate on the construction age of the Sphinx (mainly "the Final Riddle of Sphinx") and discuss a potential solution of this debate with TCN dating suggesting that archaeologists inform their scientific progeny since the time for this study would come. In addition to this exciting review, STUART (2001) summarised the principles (mainly for archaeologists) and utility of TCN methods to address archaeological questions. In his review on in-situ cosmogenic nuclides, the controls of the production of TCN in exposed surfaces are outlined and the factors of relevance for exposure dating of archaeological 
material are evaluated (STUART 2001).

Construction of the field context in surface exposure dating of archaeological structures is the most important aspect. This context should be delineated with all available archaeological and geological data and the archaeological question discussed in detail. At this point, input from the archaeologist in the construction of the context may be determinant. Many problems which would arise later during evaluation and interpretation of the results can be omitted with careful planning during this phase. After the selection of the appropriate cosmogenic isotope to be applied (Table 1), samples are collected following the strategies defined in other surface exposure dating studies (Gosse $\&$ PHILlips 2001). Not only the construction time of archaeological structures, but also collapse time can be surface exposure dated. For instance, exposure dating of blocks within the ruins of an archaeological structure can give information about the collapse event of this structure.

Several problems may arise during the building up of the field context concerning the main assumptions of surface exposure dating. Among these assumptions, the first is likely the most critical one, since the building stone (sensu lato) used for the construction has a possibility of being pre-exposed before quarrying and/or of having TCN concentration produced in depth and thus a significant concentration of inherited TCNs (Ivy-Ochs \& KoBer 2008). Although the inheritance is uncommon in practice when glacially transported erratic boulders are dated with TCNs (PuTKONEN \& SwANSON 2003), the probability for archaeological applications is more serious. This potential presence of inheriting TCN can be assessed with careful observation during sampling, particularly in the case of quarried materials. If this is not possible, the analysis of TCN concentration over a depth profile of several meters may then provide information on the inheritance and erosion rates (see Ivy-Ochs \& KoBer 2008 for further details). If the source quarry can be determined, the concentration of TCN on both exposed and buried surfaces from this quarry can be analysed. In the first instance, this difficulty looks discouraging; however it can after be eliminated within the field context and related sampling strategies in the field. Also, multiple TCN measurements may be helpful; for instance, measurements of unstable ${ }^{10} \mathrm{Be}$ and stable ${ }^{21} \mathrm{Ne}$ can be used to determine the exposure history of a given archaeological surface. ${ }^{21} \mathrm{Ne}$ concentration will clarify the total cosmogenic exposure history and, as the unstable ${ }^{10} \mathrm{Be}$ will decay in the case of any interruption in exposure, it will reveal the pattern of exposure history: either simple or complex. Simple exposure will result in ${ }^{10} \mathrm{Be}$ and ${ }^{21} \mathrm{Ne}$ ages, which are consistent within the error limits. However, a complex exposure will result in a younger ${ }^{10} \mathrm{Be}$ than ${ }^{21} \mathrm{Ne}$ age, due to the isotopic decay of ${ }^{10} \mathrm{Be}$. Although complex exposure histories are successfully applied to glacially abraded bedrock and for surfaces (BIERMAN et al. 1999; FABEL et al. 2002; PhilLIPS et al. 2006), the application to archaeology is more complex. In this case, the exposure episodes will be interrupted by either complete or partial (shielding by other agents such as soil, sediment etc...) burial, or a series of different burial times. In such a complicated situation, the only information that can be deduced is the total exposure time to radiation. The best solution to this complexity is the minimization of unknown parameters, i.e. the careful examination of the field context.

Another problem concerning exposure dating assumptions is inconstant local production rates of respective TCN during exposure time. In the case of archaeology, this inconsistency can occur through rebuilding, restoration, renovation of archaeological structures such as buildings, monuments and standing stones. These kinds of post-exposure displacement activities will directly affect the production rate and thus may result in meaningless exposure ages. As in the case of inheritance, the variable production rate problem can be omitted again by careful observation within a well structured context.

Although the possibility is quite low and uncommon, system closedness concerning the third assumption can also cause some problems. There are two ways this occurs: either some of the TCN is lost during the exposure time, such 
as chipping out of the material through physical weathering, which will result in younger exposure ages. The prevention is simple: the surface to be sampled should be selected carefully. On the other hand, a gain of TCN through atmospheric cosmogenic isotopes (see Ivy-OcHS \& KOBER 2008 for further details) such as meteoric ${ }^{10} \mathrm{Be}$ and ${ }^{36} \mathrm{Cl}$ may result in higher exposure ages. Possible contamination by meteoric isotopes is unlikely and normally removed during sample preparation due to improved chemical sample preparation in the TCN technique.

In the first study to solve an archaeological problem by surface exposure dating, Phillips et al. (1997) used ${ }^{36} \mathrm{Cl}$ to address the question of whether the exposed schist surfaces of the Côa valley (northern Portugal) were available for engraving during Palaeolithic times (from around $2.5 \mathrm{Ma}$ to around $10 \mathrm{ka}$ ago). The age of the animal and other figures engraved on these rock surfaces is controversial and hypotheses fall into two time periods: (1) Palaeolithic, due to the stylistic indications (among others ZILHÃo 1995) and (2) Holocene, suggested by radiocarbon dating (WATCHMAN 1995; 1996) and microerosion dating results (BEDNARIK 1995a; 1995b; 1995c). Phillips et al. (1997) revealed that the rock panels had been exposed long enough to be engraved during the Palaeolithic, and argued for a landscape stable enough to support Palaeolithic art (STUART 2001). Although PhILlips et al. (1997) had given a maximum exposure age (i.e. the real exposure age is probably younger) for the schist panels, this first application of TCNs was criticised by WATCHMAN (1998) and BEDNARIK (1998), with criticisms focusing mainly on inheritance (i.e. the TCN concentration present prior to the exposure), erosion rates of the schist panels and the potential contamination of meteoric ${ }^{36} \mathrm{Cl}$ due to the high hydrological and therefore hydrochemical activity in the region, i.e. this system was not closed with respect to gain of the respective isotope.

A prime example of surface exposure dating study is by Ivy-Ochs et al. (2001) who analysed two chert artifacts (flakes made during the knapping process) of Late Acheulean or early Middle Palaeolithic age from the Thebes Mountains near Luxor, Egypt. By measuring the cosmogenic ${ }^{10} \mathrm{Be}$ concentration in the artefacts they were able to calculate 'nominal exposure ages' of 326 and 304 ka respectively.

In a later study, FARLEY et al. (2001) successfully measured ${ }^{3} \mathrm{He}$ in the fluorapatite of fossil teeth, opening up the possibility of dating fossil remains at archaeological sites. On the one hand the continuous exposure requirement must be satisfied. On the other, the preliminary results of FARLEY and coworkers imply that some of the fossils they studied comprise lag deposits and are much older than the associated sediment.

The main disadvantage of surface exposure dating of archaeological structures seems to be the inheritance as was also experienced in the earlier studies. As mentioned above, the inheritance problem can mainly be omitted during the scientific context construction phase; if not possible, this can still be excluded by applying a multiple TCN approach, but even so this will be not more than a limited approach to the problem according to the present level of experience in such situations.

Surface exposure dating is a direct, absolute dating tool which can be applied to a broader time span within and beyond the ${ }^{14} \mathrm{C}$ limit. Its independence of the organic material and lithology is a key advantage compared to the other dating techniques. Furthermore, surface exposure dating can be used as an 'event' dating tool in archaeology such as construction or destruction of archaeological structures. The precision of surface exposure dating is high enough to date such archaeological events.

In particular, lower detection limit of surface exposure dating, which is around 100 years, would for instance mean that marble statues older than $19^{\text {th }}$ century can be exposure dated. This fact, in principle, would imply that TCN could be potentially used to determine whether an archaeological object is original or not. All these advantages of exposure dating are encouraging for its application to the archaeological questions. Much has been learnt from previous studies; however, there is still more to be learnt and experienced with new applications. 


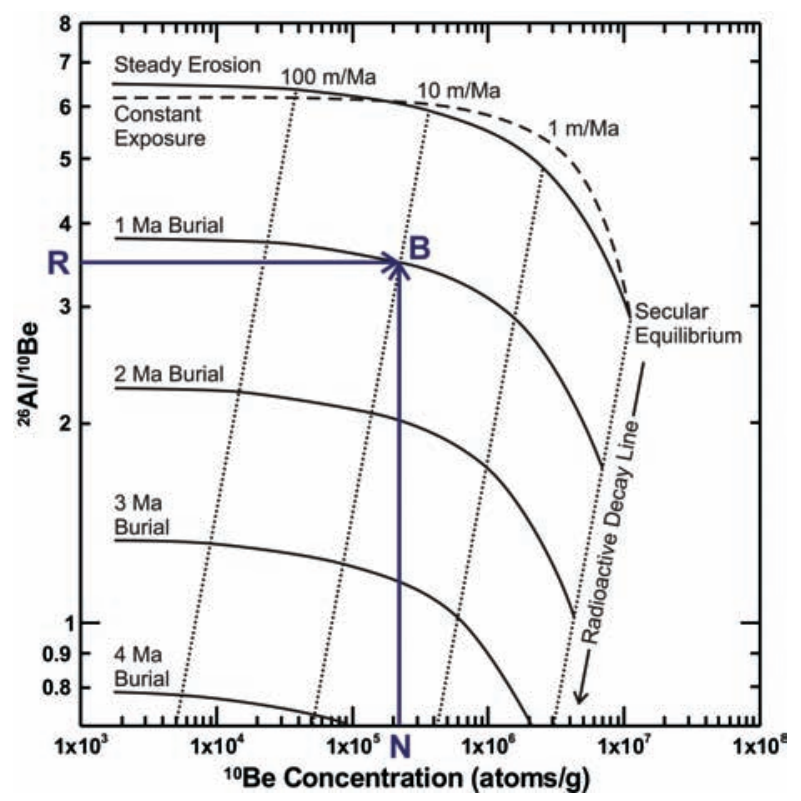

Fig. 3: Plot used in burial dating (modified from Granger \& MuZIKAR 2001). $\mathrm{R}$ is showing the ${ }^{26} \mathrm{Al} /{ }^{10} \mathrm{Be}$ ratio, $\mathrm{N}$ the ${ }^{10} \mathrm{Be}$ concentration and $\mathrm{B}$ the equivalent burial time.

Abb. 3: Diagramm zu Berechnung von Begrabungsaltern (verändert nach Granger \& MuzIKAR 2001). R ist das Verhältnis ${ }^{26} \mathrm{Al} /{ }^{10} \mathrm{Be}, \mathrm{N}$ die Konzentration an ${ }^{210} \mathrm{Be}$ und $\mathrm{B}$ die equivalente Begrabungszeit.

\subsection{Burial dating}

The application of burial dating to archaeology is a promising tool. Basically, any object of archaeological origin that has been buried can be dated with this technique (Fig. 3). Considering the period of application (from $\sim 100 \mathrm{ka}$ to $5 \mathrm{Ma}$ ), burial dating can be mainly applied to the Palaeolithic time (from around $2.5 \mathrm{Ma}$ to around $10 \mathrm{ka}$ ago). Until now, burial dating has been applied using ${ }^{10} \mathrm{Be}$ and ${ }^{26} \mathrm{Al}$ in quartz. The fundamentals are as follows: the cosmic ray cascade causes the production of TCN in quartz crystals (as sediment and/or mineral in the rock) at or near the earth's surface. When quartz grains are eroded, transported and deposited far below the surface (e.g., in a cave), the TCN production rate becomes zero due to the attenuation of the cosmic rays in the rock. The radioactive decay of ${ }^{10} \mathrm{Be}$ and ${ }^{26} \mathrm{Al}$ with time will result in a decrease in concentrations of these radionuclides in the host mineral (mainly quartz). Since ${ }^{26} \mathrm{Al}$ has a shorter half-life than ${ }^{10} \mathrm{Be}$ (Table 1 ), ${ }^{26} \mathrm{Al}$ vs. ${ }^{10} \mathrm{Be}$ ratio decreases with time and the time since the sediment was buried can principally be determined when the initial build-up is modelled (for details see DeHNERT AND SCHLÜChter 2008). For burial dating application, four requirements must be fulfilled. The first is that the accumulation of TCN in the quartz grains prior to burial must be sufficient enough for a successful AMS measurement. The second is that the transport and the burial of quartz should be contemporaneous with respect to timescales of radioactive decay. The third is that the prospective quartz sample must be buried deep enough to avoid significant TCN production after burial and the fourth requirement is that the TCN production should result from a simple history of exposure prior to burial.

The burial dating technique can be applied, for instance, to the settled caves of Palaeolithic times (e.g. PARTRIDGE et al. 2003). In principle, 
one could burial date both the artefact and the enclosing sediment. This is a reliable way to perform a cross-control of the application of TCNs, especially when other dating techniques are not applicable. Application of burial dating to archaeology is not restricted to Palaeolithic caves. Another application can be the strata of different cultures. In this situation, an archaeological stratum can be handled as a geological unit and the deposition time of the layer can be determined within given uncertainties. Burial dating can also be applied to waste disposal in antique quarries. Here, even different phases of waste disposal can be determined in relation to the original quarry phase. Burial dating can also be applied to the special cases where archaeology and natural hazards coincide. For example, a mass movement can destroy a settlement or a part of it and the buried sediment can be dated by TCN analysis.

Again, as in surface exposure dating, construction of the field context is the most important aspect. The context should be constructed in such a way as to minimize uncertainties which can potentially cause problems during consequent phases of burial dating, using all available archaeological and geological data with close cooperation between archaeologists and TCN experts. However, some problems may still appear during archaeological applications of burial dating concerning the four requirements mentioned above. Since the accelerator mass spectrometric measurement technique is able to measure very low concentrations of TCNs, the first requirement (Measurable TCN concentrations) will not cause any problem. The second requirement (Contemporaneous transport and burial) can easily be fulfilled, since the time between the production and the burial of the archaeological artefacts is considered contemporaneous compared to the radioactive halflives of ${ }^{26} \mathrm{Al}$ and ${ }^{10} \mathrm{Be}$. The third requirement (No TCN production after burial) is likely the most critical one and affects all burial dating applications. Here, on the other hand the production of TCNs at depth cannot be neglected, since there will still be some amount of TCN concentration produced after deposition and/or burial. This potential problem can be minimized by the application of an appropriate model for production after deposition. Beside the third requirement, the fourth requirement (Simple exposure history before burial) is fulfilled for artefacts by approximations following appropriate models as with other burial dating applications (for details see DeHNERT \& SCHLÜCHTER 2008).

During the last decade, burial dating has been applied to archaeological questions. BOARETTO et al. (2000) proposed the application of burial dating to archaeology with a case study from Tabun Cave, Mt. Carmel (Israel), which has a sedimentary sequence representing the type section for about the last $800 \mathrm{kyr}$ in the Levant. Flint tools are also embedded within this quartz rich sequence. In this study, flint tools as well as sediments were sampled for ${ }^{10} \mathrm{Be}$ and ${ }^{26} \mathrm{Al}$. The flints that they analyzed contained too much stable ${ }^{27} \mathrm{Al}$ and too little ${ }^{26} \mathrm{Al}$, so that their analyses were complicated. Thus, BoARETTO et al. (2000) did not calculate burial ages for these samples. The key finding of this study is that the internal environment of the flint is well sealed, so that any contamination by meteoric ${ }^{10} \mathrm{Be}$ seems to be unlikely.

Apart from the direct application of burial technique, VERRI et al. (2002, 2004, 2005) studied flints that were embedded within the sedimentary sequence in the Tabun and Qesem caves in Israel. Considering the basic idea that flint mined from deeper than $2 \mathrm{~m}$ will have a low ${ }^{10} \mathrm{Be}$ concentration, whereas flint collected from the surface or mined from shallower than $2 \mathrm{~m}$ will contain a higher ${ }^{10} \mathrm{Be}$ concentration, they determined that different flint procurement strategies, including deep mining, were used at least as early as the Late Lower Palaeolithic in the Levant. For instance, ${ }^{10} \mathrm{Be}$ concentration of flints from one layer (Lower Layer E, Acheulo - Yabrudian, around 400 - $200 \mathrm{ka}$ ) in Tabun cave are very low and consistent compared to the layers below and above (VERRI et al. 2005). Recently, PARTRIDGE et al. (2003) applied burial dating (using ${ }^{10} \mathrm{Be}$ and ${ }^{26} \mathrm{Al}$ ) to the fossiliferous breccia in the Jacovec Cavern and Silberberg Grotto at Sterkfontein, South Africa. The results of this application revealed that the ho- 
minid fossils embedded within these deposits were accumulated in the Early Pliocene, and also that burial dates obtained from Jacovec Cavern and Silberberg Grotto are indistinguishable. Approximately $4 \mathrm{Ma}$ of burial age for the hominid remains found in these two sites is also consistent with and similar to the findings from East Africa (Clarke et al. 2003; PARTRIDGe et al. 2003). In a subsequent study, Muzikar \& Granger (2006) applied a combination of cosmogenic, stratigraphic and palaeomagnetic information using a Bayesian approach to refine the burial dating results from Sterkfontein.

The main disadvantage of burial dating of archaeological artefacts seems to be post-burial TCN production and possible complicated TCN production history prior to burial as experienced also in the earlier studies. This problem can be mainly solved -as mentioned above- just during the scientific context construction phase. Especially the complexity vs. simplicity of TCN production (complex or simple exposure) prior to burial can give information about the tool procurement as demonstrated by VERRI et al. (2002, 2004, 2005). As the ${ }^{10} \mathrm{Be}$ and ${ }^{26} \mathrm{Al}$ in quartz have been used in burial dating applications until now, this can look like a disadvantage of lithology dependency, however the use of other TCNs in burial dating is still open and needs to be tested and practiced. Much has been learnt from previous applications: burial dating is applicable to a broader time span, especially to Palaeolithic, i.e. definitely far beyond the radiocarbon dating limit; and it is also a direct, absolute dating tool which is independent of the presence of organic material. Hence, these two advantages are encouraging for its application to archaeological questions, even though there is certainly still more to be learnt and experienced with new applications.

\section{Conclusions}

During the last decade, TCNs have been successfully applied to a several archaeological problems, although most of these were test applications. TCN methodology has several advantages over other dating tools: as the radiocarbon technique is widely used by archaeologists, absence of organic material is generally a problem. Moreover, increasing uncertainties with time and calibration issues are sometimes problematic. At this point, TCNs seem to be an outstanding approach in solving archaeological problems. In archaeology, TCNs can be applied (1) to a larger time period beyond the radiocarbon dating limit, (2) to all lithologies, and (3) with considerable precision. Either the production or decay of cosmogenic isotopes is used for the application of TCNs: the accumulation of TCNs will be used for surface exposure dating and their decay for burial dating. The total exposure from 100 a to $5 \mathrm{Ma}$ of a given surface of archaeological origin can be determined by measuring the concentration of the required TCN with accelerator mass spectrometry. Burial time from $\sim 0.1$ to $5 \mathrm{Ma}$ is determined by burial dating technique. Although these two types of applications have their own problems, a selective and precise discussion of the scientific and field context before and during sampling will minimize potential complications that may arise during the interpretation phase.

TCN tools, both surface exposure dating and burial dating, have, generally speaking, high potential for applications in the field of archaeology. If we assume that the total number of archaeological sites in the Eastern Mediterranean region is around 10,000 and if $<5 \%$ of these archaeological sites are suitable and available for the application of TCN analysis, then total the number of potential study applications will still number in the hundreds.

\section{Acknowledgements}

We would like to thank Dr. Frank Preusser at the University of Bern for his motivating suggestion to write this paper. We also thank Dr. Philip Hughes at the University of Manchester and Dr. Elisabetta Boaretto at the Department of Land of Israel Studies and Archaeology for their helpful comments and suggestions. We are grateful to Heather Murray and Sally Lowick at the University of Bern for her kind help 
during the preparation of this paper. This study was funded by the Swiss National Science Foundation (Project No. 200001-111878).

\section{References}

BEDRANIK, R.G. (1995a): The age of Côa valley petroglyphs in Portugal. - Rock Art Research, 12: 86-103.

BedraniK, R.G. (1995b): Côa Valley rock art analytical research program. Report to Portuguese government, 28 June 1995.

BEDRANIK, R.G. (1995c): Côa Valley petroglyphs: an obituary to the stylistic dating of Paleolithic rock-art. - Antiquity, 69: 877-883.

BEDRANIK, R.G. (1998): Cosmogenic radiation nuclides in archaeology: a response to Phillips et al. - Antiquity, 72: 811-815.

Benedetti, L., Finkel, R., King, G., Armijo, R., Papanastassiou, D., Ryerson, F., Flerit, F.J., Faber, D. \& Stavrakakis, G. (2003): Motion on Kaparelli fault (Greece) prior to the 1981 earthquake sequence determined from ${ }^{36} \mathrm{Cl}$ cosmogenic dating. - Terra Nova, 15: 118-124.

Bierman, P.R., Marsella, K.A., Patterson, C., Davis P.T. \& CAfFeE, M. (1999): Mid-Pleistocene cosmogenic minimum-age limits for preWisconsinan glacial surfaces in southwestern Minnesota and southern Baffin island: a multiple nuclide approach. - Geomorphology, 27: 25-39.

Bierman, P.R., Caffee, M.W., Davis, P.T., Marsella, K., Pavich, M., Colgan, P., Mickelson, D. \& LARSEN, J. (2002): Rates and timing of earth surface processes from in-situ produced cosmogenic ${ }^{10} \mathrm{Be}$. - Reviews in Mineralogy and Geochemistry, 50: 147-204.

Boaretto, E., Berkovits, D., Hass, M., Hui, S.K., Kaufman, A., Paul, M. \& Weiner, S. (2000): Dating of prehistoric caves sediments and flints using ${ }^{10} \mathrm{Be}$ and ${ }^{26} \mathrm{Al}$ in quartz from Tabun Cave (Israel): Progress report. - Nuclear Instruments and Methods in Physics Research Section B: Beam Interactions with Materials and Atoms, 172: 767-771.

Briner, J.P., Gosse, J.C. \& Bierman, P.R. (2006): Applications of cosmogenic nuclides to Laurentide Ice Sheet history and dynamics. - Geological Society of America Special Paper, 415: 29-42.

Cerling, T.E., Craig, H. (1994): Geomorphology and in-situ cosmogenic isotopes. - Annual Reviews of Earth and Planetary Sciences, 22: 273-317.
Clark, J.D., Beyene, Y., Woldegabriel, G., Hart, W.K., Renne, P.R., Gilbert, H., Defleur, A., Suwa, G., Katoh, S., Ludwig, K.R., Boisserie, J.R., Asfaw, B. \& White, T.D. (2003): Stratigraphic, chronological and behavioural contexts of Pleistocene Homo sapiens from Middle Awash, Ethiopia. - Nature, 423: 747-752.

Clarke, R.J., Partridge, T.C., Granger, D.E. \& CAFFeE, M.W. (2003): Dating the Sterkfontein fossils. - Science, 301: 596-597.

Dehnert, A. \& Schlüchter, C. (2008): Sediment burial dating using terrestrial cosmogenic nuclides. - Quaternary Science Journal (Eiszeitalter und Gegenwart), 57/1-2: 210-225.

Fabel, D., Stroeven, A.P., Harbor, J., Kleman, J., Elmore, D. \& Fink, D. (2002): Landscape preservation under Fennoscandian ice sheets determined from in situ produced Be-10 and Al-26. - Earth and Planetary Science Letters, 201: 397-406.

Farley, K.A, Cerling, T.E. \& Fitzgerald, P.G. (2001): Cosmogenic He-3 in igneous and fossil tooth enamel fluorapatite. - Earth and Planetary Science Letters, 185: 7-14.

Gonzalez, S., Concepcion, J.L., Hedges, R., HudDart, D., Ohman, J.C., Turner, A. \& Pompa y Padilla, J.A. (2003): Earliest Humans in the Americas: new evidence from Mexico. - Journal of Human Evolution, 44: 379-387.

Gosse, J.C. \& Phillips, F.M. (2001): Terrestrial in situ cosmogenic nuclides: theory and application. - Quaternary Science Reviews, 20: 1475-1560.

Granger, E.D. \& MuziKar, P.F. (2001): Dating sediment burial with in situ-produced cosmogenic nuclides: theory, techniques, and limitations. - Earth and Planetary Science Letters, 188: 269-281.

Heimsath, A.M., Dietrich, W.E., Nishizzumi, K. \& FINKEL, R.C. (1997): The soil production rate function and landscape equilibrium. - Nature, 388: 358-361.

Hofmann, H.J., Beer, J., Bonani, G., von Gunten, H.R., Raman, S., Suter, M., Walker, R.L., WoöFLI, W. \& ZimmermanN, D. (1987): ${ }^{10}$ Be: Half-life and AMS-standards. - Nuclear Instruments and Methods in Physics Research B, 29: 32-36.

Ivy-Ochs, S. \& Kober, F. (2007): Cosmogenic nuclides: a versatile tool for studying landscape change during the Quaternary. - Quaternary Perspectives, 16: 134-138.

Ivy-Ochs, S. \& Kober, F. (2008): Surface Exposure Dating with Cosmogenic Nuclides. - Quaternary 
Science Journal (Eiszeitalter und Gegenwart), 57/1-2: 179-209.

Ivy-Ochs, S., Wüst, R., Kubik, P.W., Müller-Beck, H. \& Schlüchter, C. (2001): Can we use cosmogenic isotopes to date stone artifacts? - Radiocarbon, 43: 759-764.

Ivy-Ochs, S., Kerschner, H., Reuther, A., Maisch, M., Sailer, R., Schaefer, J., Kubik, P. W., Synal, H.-A. \& SChlÜChter, C. (2006): The timing of glacier advances in the northern European Alps based on surface exposure dating with cosmogenic ${ }^{10} \mathrm{Be},{ }^{26} \mathrm{Al},{ }^{36} \mathrm{Cl}$, and ${ }^{21} \mathrm{Ne}$ - - Geological Society of America Special Paper, 415: 43-60.

Klein, J., Giegengack, R., Middleton, R., Sharma, P., Underwood Jr., J.R. \& Weeks, W.A. (1986): Revealing histories of exposure using in-situ produced ${ }^{26} \mathrm{Al}$ and ${ }^{10} \mathrm{Be}$ in Libyan desert glass. - Radiocarbon, 28: 547-555.

LAL, D., (1988): In situ-produced cosmogenic isotopes in terrestrial rocks. - Annual Review of Earth and Planetary Sciences, 16: 355-388.

Lal, D. \& Peters, B. (1967): Cosmic ray produced radioactivity on the earth. - In: SitTe, K. (ed.): Handbuch der Physik: 551-612; Berlin (Springer).

Licciardi, J.M., Kurz, M.D., Clark, P.U. \& Brook, E.J. (1999): Calibration of cosmogenic ${ }^{3} \mathrm{He}$ production rates from Holocene lava flows in Oregon, USA, and effects of the Earth's magnetic field. - Earth and Planetary Science Letters, 172: 261-271.

MolodKov, A. (2001): ESR dating evidence for early man at a Lower Palaeolithic cave-site in the Northern Caucasus as derived from terrestrial mollusc shells. - Quaternary Science Reviews, 20: 1051-1055.

Muzikar, P. \& Granger, D. (2006): Combining cosmogenic, stratigraphic, and paleomagnetic information using a Bayesian approach: General results and an application to Sterkfontein. - Earth and Planetary Science Letters, 243: 400-408.

NiedERMANN, S. (2000): The ${ }^{21} \mathrm{Ne}$ production rate in quartz revisited. - Earth and Planetary Science Letters, 183: 361-364.

Nishizzumi, K., Kohl, C.P., Shoemaker, E.M., Arnold, J.R., Klein, J., FinK, D. \& Middleton, R. (1991): In situ ${ }^{10} \mathrm{Be}-{ }^{26} \mathrm{Al}$ exposure ages at Meteor Crater, Arizona. - Geochimica et Cosmochimica Acta, 55: 2699-2703.

Partridge, T.C., Granger, D.E., Caffee, M.W., Clarke, R.J. (2003): Lower Pliocene hominid remains from Sterkfontein. - Science, 300: 607612 .
Phillips, F.M., Montgomery, F., Elmore, D. \& SharMA, P. (1997): Maximum ages of the Côa valley (Portugal) engravings measured with Chlorine36. - Antiquity, 71: 100-104.

Phillips, F.M., Zreda, M.G., Smith, S.S., Elmore, D., Kubik, P.W., Dorn, R.I. \& Roddy, D.J. (1991): Age and geomorphic history of Meteor Crater, Arizona, from cosmogenic ${ }^{36} \mathrm{Cl}$ and ${ }^{14} \mathrm{C}$ in rock varnish. - Geochimica et Cosmochimica Acta, 55: 2695-2698.

Phillips, W.M., Hall, A.M., Mottram, R., Fifield, L.K. \& Sugden, D.E. (2006): Cosmogenic Be10 and Al-26 exposure ages of tors and erratics, Cairngorm Mountains, Scotland: Timescales for the development of a classic landscape of selective linear glacial erosion. - Geomorphology, 73: 222-245.

Putkonen, J. \& Swanson, T. (2003): Accuracy of cosmogenic ages for moraines. - Quaternary Research, 59: 255- 261.

ReEDY, R.C., (1987): Nuclide production by primary cosmic-ray protons. - Journal of Geophysical Research, B, Solid Earth and Planets, 92: 697-702.

Ritz, J.-F., Vassallo, R., Braucher, R., Brown, E.T., CArretier, S. \& Bourlès, D. (2006): Using in situ-produced ${ }^{10} \mathrm{Be}$ to quantify active tectonics in the Gurvan Bogd mountain range (Gobi-Altay, Mongolia). - Geological Society of America Special Paper, 415: 87-110.

RoberTs, N. (1998): The Holocene. - 316 p.; Oxford (Blackwell Publishing).

Samworth, E.A., Warburto, E.K., Engelber, G.A. (1972): Beta-Decay of Al-26 Ground State. - Physical Review, C5: 138- 142.

Schaller, M., von Blanckenburg, F., Hovius, N. \& KuBIK, P.W. (2001): Large-scale erosion rates from in situ-produced cosmogenic nuclides in European river sediments. - Earth and Planetary Science Letters, 188: 441-458.

Schaller, M., Hovius, N., Willet, S.D., Ivy-Ochs, S., Synal, H.-A. \& Chen, H.-C. (2005): Fluvial bedrock incision in the active mountain belt of Taiwan from in situ-produced cosmogenic nuclides. - Earth Surface Processes and Landforms, 30: 955-971.

Shen, G., Ku, T.L., Cheng, H., Edwards, R.L., Yuan, Z. \& WANG, Q. (2001): High-precision U-series dating of Locality 1 at Zhoukoudian, China. - Journal of Human Evolution, 41: 679-688.

Stone, J.O. (2000): Air pressure and cosmogenic isotope production. - Journal of Geophysical Research - Solid Earth, 105: 23753-23759.

StUart, F.M. (2001): In situ cosmogenic isotopes: 
principles and potential for archaeology. - In: Brothwell, D.R. \& Pollard, A.M. (eds.): Handbook of Archaeological Sciences: 93-100; Chichester (John Wiley and Sons).

Valladas, H., Mercier, N., Joron, J.L., McPherron, S.P., DibBle, H.L. \& Lenoir, M. (2003): TL dates for the Middle Paleolithic site of Combe-Capelle Bas, France. - Journal of Archaeological Science, 30: 1443-1450.

VermeEsch, P. (2007): CosmoCalc: An Excel add-in for cosmogenic nuclide calculations. - Geochemistry Geophysics Geosystems, 8: Art. No. Q08003.

Verri, G., Barkai, R., Ben-Dov, Y., Boaretto, E., Bordeanu, C., Gopher, A., Hass, M., Paul, M. \& WeInER, S. (2002): ${ }^{10} \mathrm{Be}$ measurements on Neolithic and Paleolithic flint tools from Israel. -Geochimica et Cosmochimica Acta, 66: 805.

Verri, G., Barkai, R., Bordeanu, C., Gopher, A., Hass, M., Kaufman, A., Kubik, P.W., Montanari, E., Paul, M., Ronen, A., Weiner, S. \& Boaretto, E. (2004): Flint mining in prehistory recorded by in situ-produced cosmogenic ${ }^{10} \mathrm{Be}$. - PNAS, 101: 7880-7884.

Verri, G., Barkai, R., Gopher, A., Hass, M., KuBik, P.W., Paul, M., Ronen, A., Weiner, S. \&
BoAretto, E. (2005): Flint procurement strategies in the Late Lower Palaeolithic recorded by in situ produced cosmogenic ${ }^{10} \mathrm{Be}$ in Tabun and Qesem Caves (Israel). - Journal of Archaeological Science, 32: 207-213.

WALKER, M.J.C. (2005): Quaternary Dating Methods. - 286 pages; Chichester (John Wiley and Sons).

Watchman, A. (1995): Recent petroglyphs, Foz Côa, Portugal. - Rock Art Research, 12: 104-108.

Watchman, A. (1996): A review of the theory and assumptions in the AMS dating of the Foz Côa petroglyphs, Portugal. - Rock art Research, 13: 21-30.

Watchman, A. (1998): Some observations on the radiocarbon and cosmogenic dating of petroglyphs, Foz Côa, Portugal. - Antiquity, 72: 197-200.

Williams-Thorpe, O., Jenkins, G.D., Jenkins, J. \& Watson, J.S. (1995): Chlorine-36 dating and the bluestones of Stonehenge. - Antiquity, 69: 1019-1020.

ZILHão, J. (1995): The stylistically Paleolithic petroglyphs of the Côa valley (Portugal) are of Paleolithic age: a refutation of their 'direct dating' to recent times. - Antiquity, 69: 883-901. 